\title{
ANTI-OXIDANT AND ANTI-DIABETIC ACTIVITIES OF ETHANOLIC EXTRACT OF Primula denticulata FLOWERS
}

\begin{abstract}
Hemlata Bhatt ${ }^{*}$, Sarla Saklani ${ }^{1}$, Kumud Upadhayay²
1Dept Pharmaceutical Sciences, H.N.B. Garhwal University, Srinagar,Garhwal, Uttarakhand, India. 246174

2Dept Pharmaceutical Sciences,Bhimtal, Kumaun University, Nainital. Uttarakhand, India. 263136

Submitted: $13-01-2016$

Revised: 27-02-2016

ABSTRACT

The present investigation was carried out to focus on the anti-oxidant and anti-diabetic effect of ethanolic extract of flowers of Primula denticulata by DPPH, ferrous chelating, reducing power assay and streptozotocin induced diabetes respectively. Dose selection was made on the basis of acute oral toxicity study $(100 \mathrm{mg} / \mathrm{kg}, 200 \mathrm{mg} / \mathrm{kg}, 400 \mathrm{mg} / \mathrm{kg}$ bodyweight) as per OECD guidelines 423 . The blood glucose levels were measured by using blood glucose measuring strips based on glucose-oxidase method. The extract showed significant anti-oxidant and anti-diabetic activity when compared with standard drug.
\end{abstract}

Accepted: 1-04-2016

*Corresponding author Hemlata Bhatt

Email:

bhawana.sati@gmail.com

Keywords: Primula denticulata, anti-oxidant and anti-diabetic activity.

\section{INTRODUCTION}

Diabetes mellitus is a chronic disease caused by deficiency in production of insulin by the pancreas, or by the ineffectiveness of the insulin produced. Due to diabetes numerous complications occurs such as retinopathy, neuropathy and peripheral vascular insufficiencies (Chehade et al., 2000). It is considered as one of the five leading causes of death in the world. (Ahmed et al., 2010)Traditional plants are used throughout the world for the treatment of diabetes. The World Health Organization has also recommended the evaluation of traditional plant treatments for diabetes (Day, 1998).Oxidative stress which is defined as an imbalance between the generation of oxidants and antioxidant defense capacity of the body is suggested as a mechanism underlying diabetes and diabetic complications like many other diseases (Atalay et al .,2002 ). There is also evidence that higher glucose concentration causes depression on natural antioxidant defense agents such as glutathione or vitamin C (Gumieniczek et al., 2002). The increase in the levels of reactive oxygen species and free radicals cause damage in the biological structures such as cell wall, genetic material and enzymes. These oxidants also cause microvascular and macrovascular complications, cardiovascular diseases, kidney and nerve damage (Aydin et al., 2001).

$P$. denticulata belongs to the family Primulaceae is an easy-growing, rumbustious species originating from meadows and the light woodland of the Himalayas. It is also called as drumstick primula. Primula denticulata grows best in a partly shaded spot with soil that does not dry out in summer. Primula species have medicinal properties and used as antiinflammatory, bactericidal, diuretic, antitumour and hepatoprotective. (Tokalov et al., 2004) Primula denticulata contains triterpene glycosides denticin and denticulatin and flavanoid. (Ahmad et al., 1990). As there is no scientific data available regarding anti-diabetic activity of plant, the aim of the study was to investigate anti- diabetic effect of ethanolic extract by streptozotocin induced diabeties in rats, as well as to evaluate the anti-oxidant effect of ethanolic extract by three different models DPPH, ferrous chelating and reducing power assay.

\section{MATERIAL AND METHODS} Collection and authentification of plant material

$P$. denticulata was authenticated at Department of Botany H.N.B Garhwal University, Srinagar Garhwal, Uttarakhand by 
taxonomist Dr. J. K. Tewari. The flowers of Primula denticulata were collected from Rudraprayag, Garhwal, Uttarakhand, India during July-August 2010.

\section{Extraction of plant material}

The flowers of $P$. denticulata was collected and dried by means of a natural sundry. The dried plant material was powdered and subjected to hot extraction by means of soxhlet apparatus using 95\% ethanol. The solvent from total extract was distilled off and concentrate was evaporated on water bath to syrupy consistency and then evaporated to dryness.

\section{Preliminary phytochemical screening}

The qualitative chemical tests of ethanolic extract of $P$. denticulata were carried out by using standard procedure to determine the presence of various phytochemicals (Kokate, 2005),

\section{In-vitro antioxidant studies DPPH method}

The stable 1, 1-diphenyl-2-picryl hydrazyl radical (DPPH) was used for determination of free radical-scavenging activity of the extracts. On accepting hydrogen from a corresponding donor (antioxidant), its solutions lose the characteristic deep purple ( $\lambda \max 515-$ $517 \mathrm{~nm})$ colour. DPPH is very popular for the study of natural antioxidants.Antioxidants reacts with $\mathrm{DPPH}$, which is reduced to the DPPHH and as consequence the absorbance's decreased from the DPPH radical to the DPPH-H form. The degree of discoloration indicates the scavenging potential of the antioxidant compounds or extracts in terms of hydrogen donating ability. $75 \mu \mathrm{M}$ DPPH solutions in methanol were freshly prepared. Different concentrations of extract and standard ascorbic acid were added to the equal volume of methanolic solution of DPPH. After $30 \mathrm{~min}$ at room temperature, the absorbance was recorded at $517 \mathrm{~nm}$. A control reaction was carried out without the test sample. Radical scavenging activity was calculated by the following formula. $\%$ Inhibition $=\left(\mathrm{A}_{0}-\mathrm{A}_{1}\right) / \mathrm{A}_{0}$ $\mathrm{x} 100$ where $\mathrm{A}_{0}$ is the absorbance of control and $\mathrm{A}_{1}$ is the absorbance of extract or standard. $\mathrm{IC}_{50}$ values denote the concentration of sample, which is required to scavenge $50 \%$ of DPPH free radicals. $\mathrm{IC}_{50}$ value was determined by linear regression analysis from the graph plotted between $\%$ inhibition and the different concentrations of $P$. denticulata extracts as well as standarad. (Curcic et al., 2012).

\section{Ferrous chelating activity}

On $1 \mathrm{~mL}$ of each ethanolic extract (200$1000 \mu \mathrm{g} / \mathrm{mL}$ ) and standard BHT dilutions (100$400 \mu \mathrm{g} / \mathrm{mL}$ ) was added to a solution of $2 \mathrm{mM}$ ferrous chloride $(0.2 \mathrm{~mL})$. The reaction was initiated by addition of $5 \mathrm{mM}$ ferrozine $(0.4 \mathrm{~mL})$. The total volume was adjusted to $4 \mathrm{~mL}$ with ethanol. Then, the reaction mixtures were shaken vigorously and kept at room temperature for $10 \mathrm{~min}$. Absorbance of all the solutions were measured spectrophoto-metrically at $562 \mathrm{~nm}$ (Robu et al., 2012). Ferrous chelating activity was calculated by the following formula. \% ferrous chelation $=\left(A_{0}-A_{1}\right) / A_{0} \times 100$ where $A_{0}$ is the absorbance of control and $A_{1}$ is the absorbance of extract or standard.

\section{Reducing power Method}

Substances, which have reduction potential, react with potassium ferricyanide $(\mathrm{Fe} 3+)$ to form potassium ferrocyanide $(\mathrm{Fe} 2+$ ), which then reacts with ferric chloride to form ferric ferrous complex that has an absorption maximum at $700 \mathrm{~nm} .1 \mathrm{~mL}$ of each ethanolic extract $(100-400 \mu \mathrm{g} / \mathrm{mL})$, standard ascorbic acid dilutions $(20-100 \mu \mathrm{g} / \mathrm{mL})$ and control sample $(1 \mathrm{~mL}$ distilled water) was mixed with $2.5 \mathrm{~mL}$ phosphate buffer solution ( $\mathrm{pH}$ 6.6) and $2.5 \mathrm{~mL}$ potassium ferricyanide $(1 \%)$. The final reaction mixtures were properly mixed and incubated at $50^{\circ} \mathrm{C}$ for $20 \mathrm{~min}$. After incubation, the reaction mixtures were rapidly cooled and mixed with $2.5 \mathrm{~mL}$ of $10 \%$ tri chloroacetic acid. All solutions were centrifuged at $3000 \mathrm{rpm}$ for $10 \mathrm{~min}$. About $2.5 \mathrm{~mL}$ of the supernatant was taken from each reaction mixture and $2.5 \mathrm{~mL}$ distilled water and $0.5 \mathrm{~mL}$ of ferric chloride $(0.1 \%)$ was added, mixed well and allowed to stand for $10 \mathrm{~min}$. The absorbance was measured at 700nm (Maisarah et al., 2013).

\section{In vivo Antidiabetic Activity}

\section{Acute toxicity testing}

Acute toxicity was performed for all extract according to the acute toxic classic method (as per OECD guidelines 423). 
Table I. Preliminary phytochemical investigation of $P$. denticulata

\begin{tabular}{|c|c|c|}
\hline S.No & Tests & Inference \\
\hline \multirow[t]{3}{*}{1} & Alkaloids & \\
\hline & a) Dragendorff's test & - \\
\hline & b) Hager's test & - \\
\hline \multirow[t]{4}{*}{2} & Carbohydrates & \\
\hline & a) Benedict's test & + \\
\hline & b) Fehling's test & + \\
\hline & c) Molisch's test & + \\
\hline \multirow[t]{2}{*}{3} & Flavanoids & \\
\hline & a) Shinoda's test & + \\
\hline \multirow[t]{2}{*}{4} & Triterpenoids & \\
\hline & a) Liebermann -Burchard's test & + \\
\hline \multirow[t]{3}{*}{5} & Proteins & \\
\hline & a) Biuret test & + \\
\hline & b) Million's test & + \\
\hline \multirow[t]{3}{*}{6} & Steroids & \\
\hline & a) Liebermann -Burchard's test & + \\
\hline & b) Salkowaski reaction & + \\
\hline
\end{tabular}

Female albino rats were used and the animals were kept fasting for overnight providing only water, after which the extract was administered orally at the dose of $300 \mathrm{mg} / \mathrm{kg}$ and observed for $24 \mathrm{~h}$. If the mortality was observed in two out of three animals, then the dose administered was assigned as toxic dose. If the mortality was observed in one animal, then the same dose was repeated to confirm the toxic dose. If mortality was not observed, the procedure was repeated for further higher dose i.e. $2000 \mathrm{mg} / \mathrm{kg}$. One tenth of maximum dose of the extract tested for acute toxicity was selected as middle dose i.e. $200 \mathrm{mg} / \mathrm{kg}$ and double and half of middle dose was selected for higher and lower dose i.e. 400, 100mg $/ \mathrm{kg}$.

\section{Experimental induction of diabetes}

The rats were injected intraperitonially with streptozotocin $55 \mathrm{mg} / \mathrm{kg}$ b.w. dissolved in sterile citrate buffer (1M, pH 4.5). (Aslan et al., 2000, Aslan et al., 2003, and Nilufer et al.,2006) After $72 \mathrm{~h}$ treatment blood glucose levels of all the rats were determined and rats with blood glucose level above $250 \mathrm{mg} / \mathrm{dL}$ were selected for the acute study. The animals were randomly divided into six groups after the induction of diabetes. Group I contained normal animals and served as normal control. Group II served as diabetic control. Groups I and II received vehicle1\% CMC during the experiment, while the Group III received the reference standard drug glimeperide $(0.1 \mathrm{mg} / \mathrm{kg})$ and groups from IV to VI received the extract of $(100 \mathrm{mg} / \mathrm{kg}$, $200 \mathrm{mg} / \mathrm{kg}$ and $400 \mathrm{mg} / \mathrm{kg}$ ) respectively. Blood samples were collected just prior to 1, 3, 5 and $7 \mathrm{~h}$ after drug administration.

\section{RESULTS AND DISCUSSION}

Phytochemical analysis of crude extract revealed the presence of carbohydrates, flavanoids, triterpenoids, proteins and steroids (Table I). The ethanolic extract of flowers of $P$. denticulata shows significant anti-oxidant activity by DPPH method, Reducing power assay and Ferrous chelating method. The $\mathrm{IC}_{50}$ values of extract and ascorbic acid are found to be 127.68 $\mu \mathrm{g} / \mathrm{mL}$ and $6.727 \mu \mathrm{g} / \mathrm{mL}$ respectively by DPPH method (Table II). The $\mathrm{IC}_{50}$ values of extract and ascorbic acid are found to be $221.5 \mu \mathrm{g} / \mathrm{mL}$ and $43.7 \mu \mathrm{g} / \mathrm{mL}$ respectively by reducing power assay method (Table III). The $\mathrm{IC}_{50}$ values of extract and BHT are found to be $527.5 \mu \mathrm{g} / \mathrm{mL}$ and $165.63 \mu \mathrm{g} / \mathrm{mL}$ respectively by ferrous chelating method (Table IV).

This study showed no mortality up to the dose of $2000 \mathrm{mg} / \mathrm{kg}$ body weight. So, the extract is found to be safe for the experiment. 
Hemlata Bhatt

Table II. Antioxidant activity of ethanolic extract of flower of Primula denticulata by DPPH method.

\begin{tabular}{ccccc}
\hline S. No. & $\begin{array}{c}\text { EXTRACT } \\
\text { Concentration } \\
(\boldsymbol{\mu g} / \mathbf{m L})\end{array}$ & \% Inhibition & $\begin{array}{c}\text { ASCORBIC ACID } \\
\text { Concentration } \\
(\boldsymbol{\mu} \mathbf{g} / \mathbf{m L})\end{array}$ & \% Inhibition \\
\hline 1 & 100 & 43.95 & 2 & 13.22 \\
2 & 200 & 62.55 & 4 & 23.42 \\
3 & 300 & 75.32 & 6 & 43.24 \\
4 & 400 & 85.69 & 8 & 59.04 \\
5 & & 10 & 80.22 \\
& & $\mathrm{IC}_{50} 127.68 \mu \mathrm{g} / \mathrm{mL}$ & & $\mathrm{IC}_{50} 6.727 \mu \mathrm{g} / \mathrm{mL}$ \\
\hline
\end{tabular}

Table III. Antioxidant activity of ethanolic extract of flower of Primula denticulata by reducing power assay.

\begin{tabular}{ccccc}
\hline & \multicolumn{2}{c}{ EXTRACT } & \multicolumn{2}{c}{ ASCORBIC ACID } \\
\cline { 2 - 5 } S. No. & $\begin{array}{c}\text { Concentration } \\
(\boldsymbol{\mu g} / \mathbf{m L})\end{array}$ & Absorbance & $\begin{array}{c}\text { Concentration } \\
(\mu \mathrm{g} / \mathrm{mL})\end{array}$ & Absorbance \\
\hline 1 & 100 & 0.251 & 20 & 0.282 \\
2 & 200 & 0.497 & 40 & 0.48 \\
3 & 300 & 0.674 & 60 & 0.672 \\
4 & 400 & 0.884 & 80 & 0.884 \\
5 & & & 100 & 1.12 \\
& IC $50221.5 \mu \mathrm{g} / \mathrm{mL}$ & IC $5043.7 \mu \mathrm{g} / \mathrm{mL}$ \\
\hline
\end{tabular}

Table IV. Antioxidant activity of ethanolic extract of flower of Primula denticulata by ferrous chelating method.

\begin{tabular}{ccccc}
\hline EXTRACT & \multicolumn{2}{c}{ ASCORBIC ACID } \\
S. No. & $\begin{array}{c}\text { Concentration } \\
(\boldsymbol{\mu g} / \mathbf{m L})\end{array}$ & $\begin{array}{c}\mathbf{\%} \\
\text { Inhibition }\end{array}$ & $\begin{array}{c}\text { Concentration } \\
(\mu \mathrm{g} / \mathrm{mL})\end{array}$ & \% Inhibition \\
\hline 1 & 200 & 31.24 & 100 & 44.12 \\
2 & 400 & 44.5 & 200 & 52.24 \\
3 & 600 & 55.36 & 300 & 64.26 \\
4 & 800 & 67.18 & 400 & 82.21 \\
5 & 1000 & 72.55 & & $\mathrm{IC} 50$ \\
& $\mathrm{IC} 50$ & & $165.63 \mu \mathrm{g} / \mathrm{mL}$ \\
\hline
\end{tabular}

The dose $100 \mathrm{mg} / \mathrm{kg}, 200 \mathrm{mg} / \mathrm{kg}$ and $400 \mathrm{mg} / \mathrm{kg}$ body weight were selected for the model streptozotocin induced diabetes in rats. The effect of the treatment with ethanolic extract and glibenclamide on blood glucose concentration in normal fasted and diabetic rats (Tablet V) n After $7^{\text {th }}$ hour of experiment blood glucose level was found to be 254.69, 310.91, 306.62 and $293.59 \mathrm{mg} / \mathrm{dL}$ in the diabetic rats treated with glibenclamide and plant ethanolic extract (100, 200 and $400 \mathrm{mg} / \mathrm{kg}$ body weight) respectively.
In this study, the plant extract, up to the highest dose $(2000 \mathrm{mg} / \mathrm{kg}$, p.o.) used in the acute toxicity test, did not cause any death or acute toxicity symptoms in the rats. The LD50, therefore, may be greater than $4000 \mathrm{mg} / \mathrm{kg}$ (p.o.). This relatively high LD50 shows that the plant extract is non-toxic and/or safe in rats for the study. However, this study did not ascertain the doses used by the practitioners for such treatments. Streptozotocin shows diabetogenic properties by pancreatic beta cell destruction, beta cells normally regulate blood glucose levels 
Table V. Effect of ethanolic extract of the flowers of Primula denticulata on blood glucose level in streptozotocin induced diabetic rats $(\mathrm{mg} / \mathrm{dl})$ (Acute Study)

\begin{tabular}{|c|c|c|c|c|c|c|}
\hline \multirow{2}{*}{ Group } & \multirow{2}{*}{ Treatment } & \multicolumn{5}{|c|}{ Blood glucose level mg/dl ( \pm SEM) } \\
\hline & & $\mathbf{0 h}$ & $1 \mathrm{~h}$ & $3 h$ & $5 \mathrm{~h}$ & $7 \mathrm{~h}$ \\
\hline \multirow[t]{2}{*}{1.} & Normol & 95.5 & 114.12 & 112.26 & 115.72 & 104.29 \\
\hline & Nomal & \pm 0.24 & \pm 0.42 & \pm 0.55 & \pm 0.31 & \pm 0.44 \\
\hline \multirow[t]{2}{*}{2.} & Dishetic control & 290.81 & 327.21 & 306.29 & 292.62 & 314.49 \\
\hline & Diadetuc comtror & \pm 1.21 & \pm 0.64 & \pm 0.45 & \pm 0.35 & \pm 0.29 \\
\hline \multirow[t]{2}{*}{3.} & Diabetic + glibenclamide & 298.72 & $290.50^{*}$ & $279.43^{* *}$ & $270.34^{* *}$ & $254.69 * *$ \\
\hline & $(10 \mathrm{mg} / \mathrm{kg})$ & \pm 0.53 & \pm 0.56 & \pm 0.30 & \pm 0.98 & \pm 0.88 \\
\hline \multirow[t]{2}{*}{4.} & Diabetic + extract $(100 \mathrm{mg} / \mathrm{kg})$ & 325.67 & 320.47 & 315.81 & 314.71 & 310.91 \\
\hline & & \pm 0.85 & \pm 0.63 & \pm 0.14 & \pm 0.43 & \pm 0.71 \\
\hline \multirow[t]{2}{*}{5.} & Diabetic + extract $(200 \mathrm{mg} / \mathrm{kg})$ & 316.31 & 312.26 & 311.34 & $308.64 *$ & $306.62^{*}$ \\
\hline & & \pm 0.29 & & \pm 0.54 & \pm 0. & \pm 0.66 \\
\hline 6. & Diabetic + extract $(400 \mathrm{mg} / \mathrm{kg})$ & $\begin{array}{l}305.44 \\
\pm 0.22\end{array}$ & $\begin{array}{l}301.51 \\
\pm 0.21\end{array}$ & $\begin{array}{l}298.1^{*} \\
\pm 0.45\end{array}$ & $\begin{array}{l}294.62^{*} \\
+0.54\end{array}$ & $\begin{array}{l}293.59 * \\
+0.66\end{array}$ \\
\hline
\end{tabular}

$*_{\mathrm{p}}<0.05,{ }^{*} \mathrm{p}<0.01$ significant compared to diabetic control

by producing the hormone insulin. Streptozotocin has been widely used to induce diabetes in experimental animals (Junod et al., 1969). STZ also induces oxidative stress or relative overload of oxidants i.e. reactive oxygen species (Wright et al., 1999). P.denticulata flower extract shows very significant invitro anti-oxidant activity.Various studies have shown that diabetes is associated with increased formation of free radicals and a decrease in antioxidant potential. The antioxidant and antidiabetic activity may be due to the presence of flavanoids and triterpenoid saponins. ( Tokalov et al., 2004 and Ahmad et al.,1990)

\section{CONCLUSION}

The results revealed that P.denticulata possess significant antidiabetic and anti-oxidant activity by streptozotocin induced diabetic rats and DPPH method, reducing power assay and ferrous chelating method respectively. Further studies are necessary to elucidate the mechanism of action at cellular levels and components present it.

\section{REFERENCES}

Ahmed M.F., 2010. Anti diabetic Activity of Vinca rosea Extracts in Alloxan-Induced Diabetic Rats. Int J Endocrinology.1-6.
Ahmad VU., Sultana V., Saqib QN., 1990. Triterpenoid saponins from Primula denticulata. Planta Med. 56(1):94-7.

Aslan M., Sezik E.,Yeşilada E., 2000. Antihyperglycaemic effect of Cannabis sativa L. fruits. J. Fac. Pharm. Gazi University-GUEDE. 17:89-93.

Aslan M., Sezik E.,Yeşilada E., 2003. Effect of Hibiscus esculentus L. seeds on blood glucose levels in normoglycaemic, glucose-hyperglycaemic and streptozotocin induced diabetic rats. $J$. Fac. Pharm. Gazi University-GUEDE. 20:1-7.

Atalay M. and Laaksonen D.E., 2002. Diabetes, oxidative stress and physical exercise.J. Sports Sci. \& Med. 1:1-14.

Aydın A., Orhan H., Sayal A., Özata M., Şahin G. and Işımer A., 2001.Oxidative stress and nitric oxide related parameters in type II diabetes mellitus: effects of glycemic control. Clin. Biochem. 34: 65-70.

Chehade J.M.; Mooradian A.D.A., 2000. Rational approach to drug therapy of type 2 Diabetes Mellitus, disease management. Drugs. 60: 95-113.

Curcic M. G., Stankovic M. S., Radojevic I. D., Stefanovic O. D., Comic L. R., Topuzovic M. D., Dacic D. S., Markovic S. D., 2012. Biological effects, Total phenolic content and Flavanoid 
concentrations of fragrant yellow onion (Allium flavum L.).Medicinal Chemistry. 89(1):1-6.

Day C., 1998. Traditional plant treatments for diabetes mellitus: pharmaceutical foods. Br. J. Nutr. 80: 5-6.

Gumieniczek A., Hopkala H., Wojtowicz Z. and Nikolajuk J., 2002. Changes in antioxidant status of heart muscle tissue in experimental diabetes in rabbits. Acta Biochem. Pol. 49 (2): 529-535.

Junod A.; Lambert A.E.; Stauffacher W.; Renold A.E., 1969. Diabetogenic action of streptozotocin: Relationship of dose to metabolic response. J. Clin. Invest., 48 : 2129-2139.

Kokate C K., 2005. Practical Pharmacognosy, Vallabh prakashan,New Delhi ,India, 107-111.

Maisarah A. M., Nurul Amira B., Asmah R., Fauziah O., 2013. Antioxidant analysis of different parts of Carica papaya. International Food Research Journal. 20(3):1043-1048.

Nilufer Sendogdu., Mustafa Aslan., Didem Deliorman., Fatma Ergun., Erdem yesilada., 2006..Antidiabetic and Antioxidant effects of Viris vinifera L. leaves in streptozotocin diabetic rats. Turkish. J. Pharm. Sci. 3(1): 7-18,

Robu S., Aprotosoaic A.C., Miron A.,Cioanca O., Stanescu U., Hancianu M., 2012.Invitro antioxidant activity of ethanolic extracts from some Lavandula species cultivated in Domania. Farmacia. 60(3):394-401.

Tokalov SV., Kind B., Wollenweber E., Gutzeit HO., 2004. Biological effects of epicuticular flavonoids from Primula denticulata on human leukemia cells. J Agric Food Chem. .52(2) : 239-45.

Sunil Kumar., Vipin Kumar., Om Prakash., 2011. Antidiabetic and antihyperlipidemic effects of Dillenia indica (L.) leaves extract. Brazilian Journal Pharmaceutical Sciences .47(2) : 373-378.

Wright J.R.; Abraham C.; Dickson B.C.; Yang H.; Morrison C.M., 1999. Streptozotocin dose response curve in tilapia, a glucoseresponsive teleost fish. Gen. Comp. Endocrinol. 114 : 431-440. 